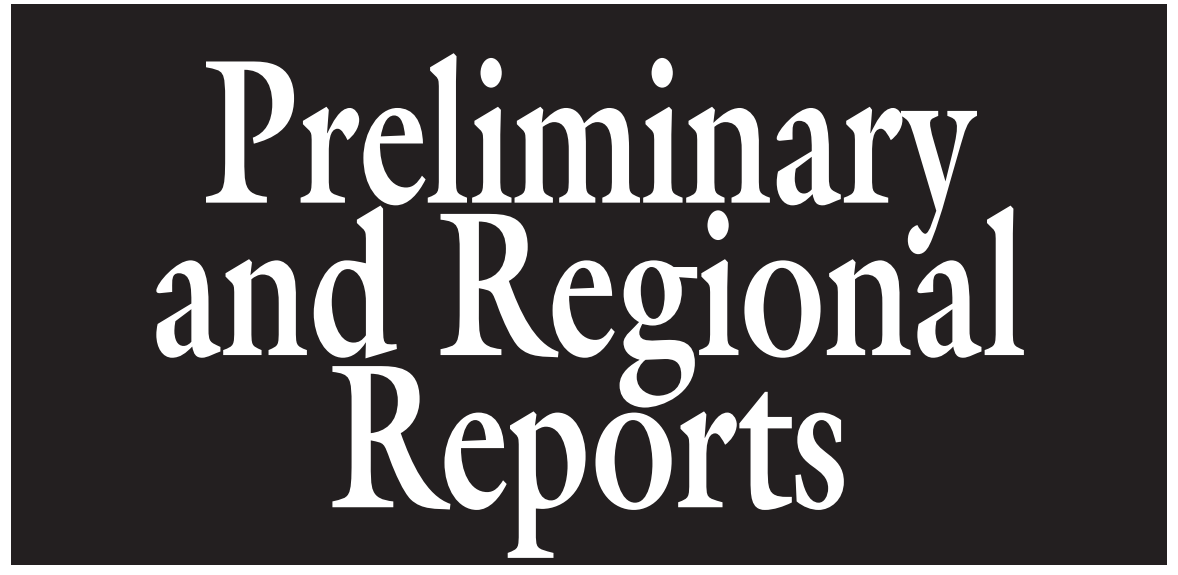

\title{
Winter 2011 Low-temperature Injury to Stone Fruit Flower Buds in New Mexico
}

\author{
Shengrui $\mathrm{Yao}^{1}$
}

Additional Index words. Prunus persica, Prunus armeniaca, Prunus salicina, Prunus domestica, Prunus avium, Prunus cerasus, winterhardiness

Summary. Twelve peach (Prunus persica) cultivars, six apricot (Prunus armeniaca) cultivars, two japanese plum (Prunus salicina) cultivars, three european plum (Prunus domestica) cultivars, four sweet cherry (Prunus avium) cultivars, and three tart cherry (Prunus cerasus) cultivars were monitored for winter damage at New Mexico State University's Sustainable Agriculture Science Center in Alcalde, NM (main site), and the Agricultural Science Center in Los Lunas, NM (minor site), in 2011. Uncharacteristically low temperatures on $1 \mathrm{Jan}$. and $3 \mathrm{Feb}$. were recorded as -7.2 and $-11.3^{\circ} \mathrm{F}$, respectively, at Alcalde, and 4.8 and $-13.9^{\circ} \mathrm{F}$, respectively, at Los Lunas. On $10 \mathrm{Jan}$. at Alcalde, live peach flower bud percentage varied by cultivar, ranging from $11 \%$ for Blazingstar to $25 \%$ for PF-1, and $85 \%$ to $87 \%$ for Encore and China Pearl. Apricot flower buds were hardier, with 70\% survival for 'Perfection', 97\% for 'Sunglo', and 99\% for 'Harglow' on 10 Jan. By 10 Feb., almost all peach flower primordia were discolored, with no cultivar showing more than $1 \%$ survival. Based on this information, the $10 \%$ kill of flower buds for most peach cultivars occurred at temperatures equal to or slightly higher than $-7.2{ }^{\circ} \mathrm{F}$, and $90 \%$ kill occurred between -7.2 and $-11.3{ }^{\circ} \mathrm{F}$. On $10 \mathrm{Feb}$., $0 \%$ to $15 \%$ of apricot flower buds on spurs or shoots of the middle and lower canopy had survived. For vigorous shoots in the upper canopy, apricot flower buds on 1-year-old shoots had a higher blooming rate than those on spurs of 2 -year-old or older wood. Flower buds of japanese plum were also severely damaged with less than $\mathbf{0 . 2 \%}$ survival for 'Santa Rosa' and $4.8 \%$ for 'Methley', but european plum were relatively unaffected with over $98 \%$ flower bud survival for 'Castleton' and 'NY6', and 87\% for 'Stanley' after $-11.3^{\circ} \mathrm{F}$ at Alcalde. Cherry-especially tart cherry-survived better than peach, apricot, and japanese plum after all winter freezes in 2011.

$\mathrm{N}$ ormally, late frost, rather than the winter freezes, is the critical challenge for fruit growers in northern and central New Mexico and nearby states (Murray and Larsen,
2011). However, in 2011, there was an unusual cold snap around New Year's Day and an even more severe one in early February. Crops across the state suffered various kinds of winter damage depending on their hardiness and location. For fruit crops, stone fruit suffered more damage than pome fruit. The last disastrous freeze happened in Jan. $1971\left(-34^{\circ} \mathrm{F}\right.$; Alcalde, NM) (Matta et al., 1982), which killed apple trees and adversely affected the tree fruit industry in northern New Mexico [New Mexico Department of Agriculture, New Mexico State University (NMSU), and U.S. Department of Agriculture (USDA), 1979]. However, there was no detailed documentation of the influence of the 1971 freeze on bud survival and fruit production. The objective of this report is to summarize the 2011 winter damage and compare the relative hardiness of different fruit species and cultivars in New Mexico, which will serve as a good future reference for researchers, fruit growers, and home gardeners in New Mexico and other semiarid regions.

\section{Materials and methods}

Stone fruit demonstration orchards have been planted in 2002 at NMSU's Sustainable Agriculture Science Center at Alcalde (northern New Mexico), and in 2007 at NMSU's Agricultural Science Center at Los Lunas (central New Mexico). Both plantings included several cultivars of peach, apricot, japanese plum, european plum, sweet cherry, and tart cherry. Alcalde (major site for this study) is located in USDA plant hardiness zone $5 \mathrm{~A}$ (Cathy, $1990)$ at lat. $36^{\circ} 05^{\prime} 27.94^{\prime \prime} \mathrm{N}$, long. $106^{\circ} 03^{\prime} 24.56^{\prime \prime} \mathrm{W}$, and $5700 \mathrm{ft}$ elevation; Los Lunas (minor site for this study) is in USDA zone 6B (Cathy, $1990)$ at lat. $34^{\circ} 46^{\prime} 08.09^{\prime \prime} \mathrm{N}$, long. $106^{\circ} 45^{\prime} 40.63^{\prime \prime} \mathrm{W}$, and $4840 \mathrm{ft}$ elevation. The frost-free $\left(32^{\circ} \mathrm{F}\right)$ period is typically from mid-May to early October at Alcalde and from early May to mid-October at Los Lunas (NMSU, 2011). All the detailed flower bud survival counts and dissection were done at the Alcalde Center, but we checked the peach and apricot flower bud winter damage during blooming time at Los Lunas. Most cultivars had four trees at both locations
Department of Plant and Environment Sciences, Sustainable Agriculture Science Center at Alcalde, New Mexico State University, Alcalde, NM 87511

The author thanks Steve Guldan and Geno Picchioni from New Mexico State University for their critical review of the manuscript. This project is a contribution of the New Mexico Agricultural Experiment Station, New Mexico State University, Las Cruces, NM.

${ }^{1}$ Corresponding author. E-mail: yaos@nmsu.edu.

\begin{tabular}{llll}
\hline $\begin{array}{l}\text { Units } \\
\text { To convert U.S. to SI, } \\
\text { multiply by }\end{array}$ & U.S. unit & SI unit & $\begin{array}{l}\text { To convert SI to U.S., } \\
\text { multiply by }\end{array}$ \\
\hline 0.3048 & $\mathrm{ft}$ & $\mathrm{m}$ & 3.2808 \\
2.54 & inch $(\mathrm{es})$ & $\mathrm{cm}$ & 0.3937 \\
25.4 & inch $(\mathrm{es})$ & $\mathrm{mm}$ & 0.0394 \\
$\left({ }^{\circ} \mathrm{F}-32\right) \div 1.8$ & ${ }^{\circ} \mathrm{F}$ & ${ }^{\circ} \mathrm{C}$ & $\left(1.8 \times{ }^{\circ} \mathrm{C}\right)+32$
\end{tabular}


(some cultivars had less than four due to tree losses for various reasons). All stone fruit species at Alcalde were in our certified organic plot with sprinkler irrigation. No fertilizer was applied in 2010 and 2011. There were white clover and grasses on the orchard floor, and they were mowed regularly. Pests were managed commercially. Peach trees on Halford rootstock were trained as perpendicular $\mathrm{V}$ system at $6 \times 15$-ft plant spacing. The other species were at a spacing of $15 \times 15-\mathrm{ft}$ with modified central leader systems. Peach, tart cherry, and european plum had some crop, and apricot and sweet cherry barely had any crop due to late frosts in 2010. Peach trees at Alcalde were pruned during the first 2 weeks of Dec. 2010 , and plum and cherry were pruned lightly in Mar. 2011. Apricot trees were not pruned during Winter 2009-10 nor during Winter 2010-11 at Alcalde. All trees at Los Lunas were under conventional management and peach trees at Los Lunas were not pruned during Winter 2010-11.

Peach and apricot. In 2011, there were severe freezes on 1 Jan. and in early February throughout New Mexico (Fig. 1) (New Mexico Climate
Center, 2007). Chilling hours between 32 and $45^{\circ} \mathrm{F}$ were calculated from 20 Sept. 2010 to 1 Jan. 2011 and 3 Feb. 2011 (University of California, Davis, 2011). One week to $9 \mathrm{~d}$ after the freezes (10 Jan. and 10 Feb.), peach shoot samples were collected from the central canopy of the trees. Several hundred peach flower buds per cultivar were dissected, and peach flower bud survival evaluation was grouped according to shoot length: short $(<5 \mathrm{~cm})$, medium $(5-15 \mathrm{~cm})$, and long $(>15 \mathrm{~cm})$. Each length category had at least 10 shoots per cultivar. For apricot, shoots of different lengths were collected on the central part of the canopy on 10 Feb. Flower buds were dissected vertically to the central part to allow visual examination of the flower organs during the dormant season. If the flower primordium was brown or black in color, it was recorded as damaged; if the flower primordium was fresh green in color, it was recorded as alive.

Flower buds or flowers were also examined around bloom time on 26 Mar. for apricot and 8 April for peach at Alcalde. For peach, all the flowers and balloon stage buds were counted for each tree. For apricot, 12-15 unpruned long branches from the upper canopy per cultivar were sampled and the flower buds from 1 -year-old shoots were separated from the flower buds from spurs of 2-year-old branches; the small flower buds appearing as dormant were counted as dead and the flowers and balloon stage buds were counted as alive. For the Los Lunas site, peach and apricot were visually evaluated on 17 Mar. for flower bud winter damage.

Plum and Cherry. Plum flower bud damage was evaluated on 26 Mar., and cherry flower bud damage was evaluated on 14 April using the same criteria as peaches and apricots at Alcalde. For cherry, we also examined the flowers for pistil damage. Flowers were counted as damaged if the pistils were black/brown in color.

No statistical tests were performed for the flower bud survival data due to lack of replicates. Only flower bud survival percentages are listed in the tables. However, with the large sample number, the flower bud survival rates are good indicators of cold hardiness.

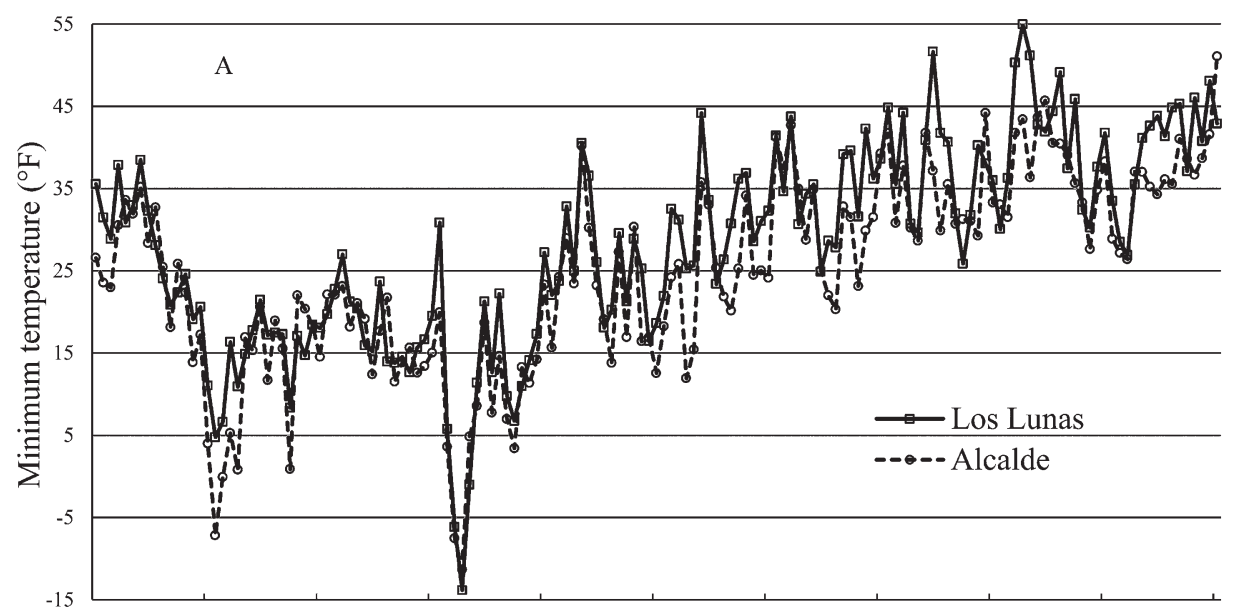

16 Dec. 201031 Dec. 201015 Jan. 201130 Jan. 2011 14 Feb.2011 1 Mar. 2011 16 Mar. 2011 31 Mar. 2011 15 Apr. 201130 Apr. 201115 May 2011
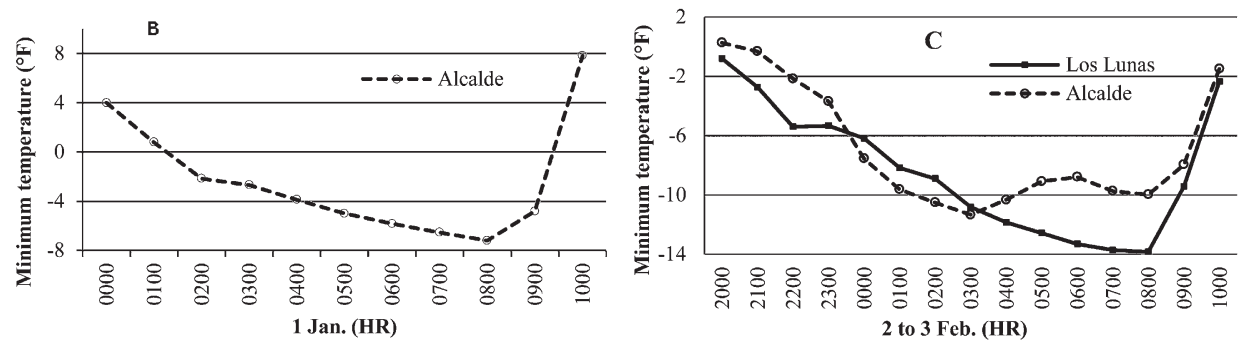

Fig. 1. (A) Minimum air temperatures from mid-Dec. 2010 to mid-May 2011 at Los Lunas and Alcalde, NM. (B) The hourly minimum temperature changes at Alcalde from 0000 to $1000 \mathrm{HR}$ on $1 \mathrm{Jan}$. 2011. (C) The hourly minimum temperature changes from $2000 \mathrm{HR}$ on $2 \mathrm{Feb}$. to $1000 \mathrm{HR}$ on $3 \mathrm{Feb} .2011$ at Los Lunas and Alcalde (New Mexico Climate Center, 2007); $\left({ }^{\circ} \mathrm{F}-32\right) \div 1.8={ }^{\circ} \mathrm{C}$. 


\section{Results and discussion}

Minimum TEMPERATURES FROM Dec. 2010 to May 2011. On l Jan. 2011, Alcalde, NM, experienced a low temperature of $-7.2^{\circ} \mathrm{F}$, and on $3 \mathrm{Feb}$. the temperature reached $-11.3^{\circ} \mathrm{F}$; and in Los Lunas, NM, the lowest temperature was $-13.9^{\circ} \mathrm{F}$, recorded on 3 Feb. (Fig. 1A). At Alcalde, the duration of low temperature below $-10^{\circ} \mathrm{F}$ was $3 \mathrm{~h}$, whereas at Los Lunas, the hourly minimum temperature below $-12{ }^{\circ} \mathrm{F}$ lasted for $4.5 \mathrm{~h}$ (Fig. 1C).

On 1 Jan. 2011, the chilling hour accumulation was $766 \mathrm{~h}$ and $1010 \mathrm{~h}$ on 3 Feb. 2011 at Alcalde. So, the chilling hours had not been met for high chilling requirement cultivars on 1 Jan., but on 3 Feb., most cultivars had received enough chilling hours. At the end of January, the high temperatures reached $50-60{ }^{\circ} \mathrm{F}$ for 5-7 $\mathrm{d}$ at both locations (data not shown), which could make the flower buds more vulnerable to the early February freeze, especially those cultivars with a low chilling requirement.

For the late frosts, Alcalde reached 23 and $20^{\circ} \mathrm{F}$ on 24 Mar. and 25 Mar., respectively; whereas Los Lunas reached 28 and $25^{\circ} \mathrm{F}$ on 23 Mar. and 11 Apr., respectively. Both locations experienced a low temperature of $27^{\circ} \mathrm{F}$ on 3 May 2011, which killed the majority of the leftover fruit at both locations.

Peach flower bud damage. There was no correlation between flower bud survival and shoot length, except for 'Contender' $(r=0.93)$. The flower bud survival data were therefore combined and not differentiated based on shoot lengths. After the I Jan. freeze, the flower bud survival rate measured on $10 \mathrm{Jan}$. varied among cultivars, from $11 \%$ for Blazingstar to $85 \%$ and $87 \%$ for Encore and China Pearl, respectively (Fig. 2A; Table 1). On the other hand, after the 3 Feb. deep freeze, no cultivar had more than $1 \%$ healthy flower buds as of 10 Feb., which was verified at blooming time with only 0-14 flowers per tree depending on cultivar (Fig. 2B; Table 1). Because of sampling discrepancy, the live bud percentages of some cultivars on 10 Feb. (Table 1) were not of the same order as flowers/tree on 8 April. But in general, the data from those two dates expressed the same fact-over
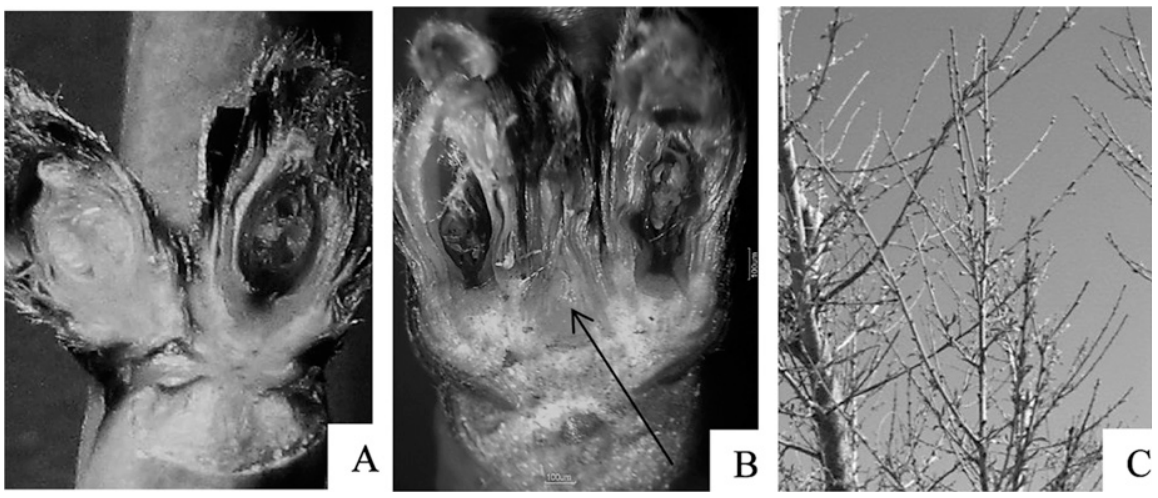

Fig. 2. 'China Pearl' peach flower buds and vegetative bud after 1 Jan. and 3 Feb. 2011 freezes at Alcalde, NM, and shoot winter damage of 'Galaxy' peach at Los Lunas, NM. (A) Live vs. winter-damaged flower buds of 'China Pearl' on 10 Jan. 2011. (B) Live vegetative bud (center one with arrow) vs. damaged flower buds of 'China Pearl' on 17 Feb. 2011. (C) Damaged shoot or shoot tips of 'Galaxy' peach on 28 Mar. 2011 at Los Lunas, NM.

Table 1. Peach flower bud winter damage evaluated in Jan., Feb., and Apr. 2011 at Alcalde, NM.

\begin{tabular}{|c|c|c|c|c|c|}
\hline \multirow[b]{2}{*}{ Cultivar } & \multicolumn{2}{|c|}{10 Jan. 2011} & \multicolumn{2}{|c|}{10 Feb. $2011^{\mathrm{z}}$} & \multirow{2}{*}{$\begin{array}{c}8 \text { Apr. } 2011 \\
\text { Flowers } \\
(\text { no. } / \text { tree })\end{array}$} \\
\hline & $\begin{array}{c}\text { Total buds } \\
\text { (no.) }\end{array}$ & $\begin{array}{c}\text { Live buds } \\
(\%)\end{array}$ & $\begin{array}{c}\text { Total buds } \\
\text { (no.) }\end{array}$ & $\begin{array}{c}\text { Live buds } \\
(\%)\end{array}$ & \\
\hline Blazingstar & 641 & 11 & 453 & 0.7 & 0.5 \\
\hline PF-1 & 1238 & 25 & 479 & 0.4 & 0.5 \\
\hline China Pearl & 465 & 87 & 487 & 0.6 & 5.5 \\
\hline Saturn & $\mathrm{n} / \mathrm{a}$ & $\mathrm{n} / \mathrm{a}$ & 428 & 0.5 & 2.3 \\
\hline Crimson Rocket & $\mathrm{n} / \mathrm{a}$ & $\mathrm{n} / \mathrm{a}$ & 293 & 0.3 & 2.0 \\
\hline Encore & 958 & 85 & 353 & 0.0 & 11.0 \\
\hline Contender & 387 & 61 & 401 & 0.0 & 14.0 \\
\hline Redhaven & $\mathrm{n} / \mathrm{a}$ & $\mathrm{n} / \mathrm{a}$ & 314 & 0.0 & 0.0 \\
\hline Surecrop & 662 & 40 & 420 & 0.0 & 0.0 \\
\hline Intrepid & 563 & 81 & 243 & 0.0 & 4.0 \\
\hline Nectar & 382 & 71 & 106 & 0.0 & 1.0 \\
\hline Sure Prince & $\mathrm{n} / \mathrm{a}$ & $\mathrm{n} / \mathrm{a}$ & 173 & 0.0 & 0.3 \\
\hline
\end{tabular}

${ }^{\mathrm{z}}$ The dead flower buds on $10 \mathrm{Feb}$. included the buds that died from the 1 Jan. freeze.

$\mathrm{n} / \mathrm{a}=$ not applicable

99\% of flower buds were killed. The few live flower buds were always either on the base of the branches or on the strong water sprouts in the upper part of the canopy, which is in accordance with previous observations (Meyer and Okie, 1986).

All flower buds of all 20 peach cultivars were killed with no bloom at Los Lunas after the $-13.9{ }^{\circ} \mathrm{F}$ temperature on 3 Feb. Unfortunately, with the $100 \%$ killing temperature, we could not differentiate the relative cultivar flower bud hardiness at Los Lunas. Peach growers in central and northern New Mexico all confirmed that there were no blooms in 2011, except for a few peach trees in the Albuquerque urban area or orchards which had warmer microclimates.
Based on this information, 10\% peach flower bud kill occurred for most cultivars after the sustained temperature drop of $-7.2^{\circ} \mathrm{F}$ ( $4 \mathrm{~h}$ below $-5{ }^{\circ} \mathrm{F}$ ) and $90 \%$ kill occurred at $-11.3^{\circ} \mathrm{F}$ ( 3 h below $-10^{\circ} \mathrm{F}$ ) (Fig. $1 \mathrm{~B}$ and $\mathrm{C}$ ). The low temperature of $-13.9^{\circ} \mathrm{F}(4.5 \mathrm{~h}$ below $-12^{\circ} \mathrm{F}$ ) as observed in Los Lunas killed $100 \%$ of peach flower buds. Even though the $10 \%$ or $90 \%$ killing temperatures would vary depending on location and preceding weather patterns before the deep freeze (Meyer and Okie, 1986; Young, 1987), this temperature range gives growers an indication of potential damage if they are in geographic areas similar to New Mexico.

No vegetative bud damage was observed for the pruned peach trees at Alcalde and the unpruned peach trees 
Table 2. Apricot flower bud winter damage for middle and lower canopy evaluated in Jan. and Feb. 2011 and for upper canopy evaluated in Mar. 2011 at Alcalde, NM.

\begin{tabular}{|c|c|c|c|c|c|c|c|c|}
\hline \multirow[b]{3}{*}{ Cultivar } & \multirow{2}{*}{\multicolumn{2}{|c|}{10 Jan. $2011^{\mathrm{z}}$}} & \multirow{2}{*}{\multicolumn{2}{|c|}{$10 \mathrm{Feb} .2011$}} & \multicolumn{4}{|c|}{26 Mar. $2011^{y}$} \\
\hline & & & & & \multicolumn{2}{|c|}{ 2-yr-old wood } & \multicolumn{2}{|c|}{ 1-yr-old shoots } \\
\hline & $\begin{array}{c}\text { Total } \\
\text { buds (no.) }\end{array}$ & $\begin{array}{c}\text { Live } \\
\text { buds (\%) }\end{array}$ & $\begin{array}{c}\text { Total } \\
\text { buds (no.) }\end{array}$ & $\begin{array}{c}\text { Live } \\
\text { buds (\%) }\end{array}$ & $\begin{array}{c}\text { Total } \\
\text { buds (no.) }\end{array}$ & $\begin{array}{c}\text { Live } \\
\text { buds (\%) }\end{array}$ & $\begin{array}{c}\text { Total } \\
\text { buds (no.) }\end{array}$ & $\begin{array}{c}\text { Live } \\
\text { buds (\%) }\end{array}$ \\
\hline Goldcot & & & 660 & 0.3 & 1184 & 3.0 & 2812 & 6.1 \\
\hline Harglow & 1462 & 99 & 859 & 8.3 & 875 & 17.1 & 1552 & 39.6 \\
\hline Harlayne & & & 357 & 16.8 & 1664 & 16.2 & 1113 & 48.5 \\
\hline Sunglo & 1711 & 97 & 666 & 9.0 & 1331 & 14.7 & 1745 & 54.9 \\
\hline Average & 1499 & 89 & 553.5 & 5.7 & 1304.5 & 8.6 & 1804 & 26.2 \\
\hline
\end{tabular}

${ }^{2}$ The flower buds dissected on $10 \mathrm{Jan}$. and $10 \mathrm{Feb}$. were from the middle and lower canopy.

${ }^{y}$ The flower buds observed on 26 Mar. were from the upper canopy, with buds from 1-year-old shoots and buds from spurs on 2-year-old wood separated.

at Los Lunas, except in 'Galaxy', which had shoot tip or small shoot damage (Fig. 2C).

Apricot FlOWER BUd DAMAge. At Alcalde, 'Perfection' had 70\% live flower buds, whereas 'Sunglo' and 'Harglow' had $97 \%$ to $99 \%$ survival on 10 Jan. (Table 2). The other cultivars were not evaluated since most of them had enough live flower buds for a crop at that time ( $10 \%$ live flower buds is the commonly accepted criterion for a reasonable crop) (Meyer and Okie, 1986; Murray and Larsen, 2011). However, after the 3 Feb. freeze, 'Goldcot', 'Perfection', and 'Puget Gold' all had less than 1\% live flower buds, whereas 'Harglow', 'Harlayne', and 'Sunglo' had 8\% to $16.8 \%$ live flower buds for those shoots on the middle and lower parts of the canopy.

For the apricot trees at Alcalde, it was a light bloom year for all cultivars and there was very limited bloom in the middle and lower parts of the canopy, which confirmed the data from 10 Feb. (Table 2). Most blooms were located on the top of the canopy (Fig. 3A and B). Flower buds on the 1 -year-old shoots had a higher survival rate than buds on spurs of 2 -year-old shoots at Alcalde (Table 2 ). Flower buds on 1 -year-old shoots also bloomed later than those on 2 year-old shoots, which helped them to survive the 23 Mar. freeze. On 23 Mar., flower buds on 2-year-old or older wood for most cultivars were in full bloom or 1-2 d after full bloom, whereas those flower buds on 1 -yearold shoots were still in balloon stage. 'Sunglo', 'Harlayne', and 'Harglow' had good fruit set on 1-year-old shoots until 27 Apr., but they were damaged by late frosts on 28 Apr. and
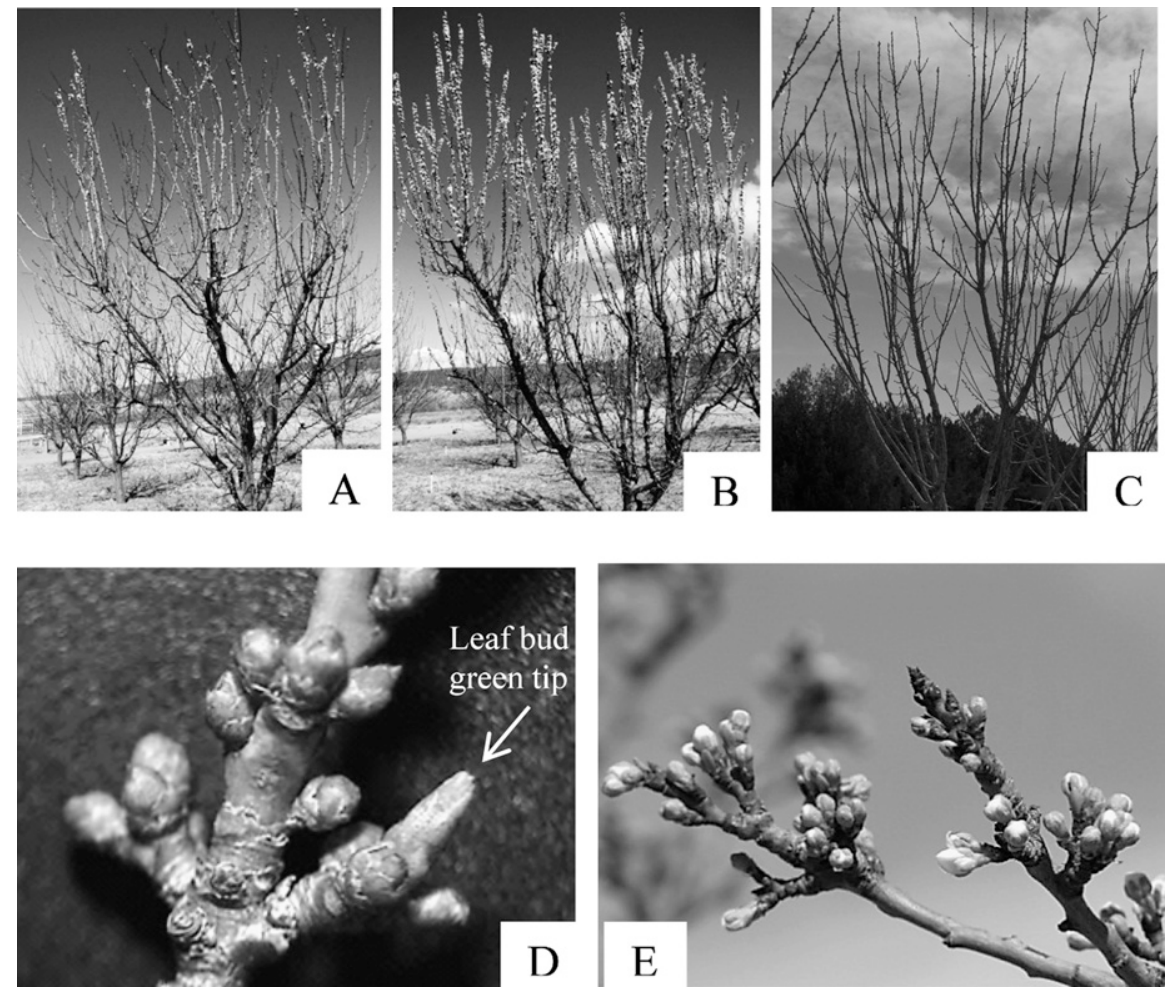

Fig. 3. Winter damage of 'Perfection' and 'Sunglo' apricot on 27 Mar. 2011, and plum flower buds at bloom time at Alcalde, NM. (A) 'Perfection' apricot with few blooms on 27 Mar. 2011. (B) 'Sunglo' apricot with more blooms than 'Perfection' apricot on 27 Mar. 2011; flowers were concentrated on the 1-year-old shoots of the upper canopy. (C) 'Goldrich' apricot at bloom time at Los Lunas on 17 Mar. 2011. (D) Winter damage of flower buds of 'Santa Rosa' plum on 28 Mar. 2011. When vegetative buds leafed out (arrow), the flower buds should have been in full bloom instead of dormant stage. (E) Live 'NY6' plum flower buds on 1 Apr. 2011.

3 May (fruit $1.5-2.0 \mathrm{~cm}$ in diameter), with no fruit left for the 2011 season at Alcalde.

Among the six cultivars at Alcalde, Sunglo, Harlayne, and Harglow were hardier than Goldcot, Puget Gold, and Perfection. 'Perfection' was the most vulnerable cultivar to winter damage and to late frost since it was the first to bloom among the six cultivars tested. With a lower early February minimum temperature, apricot at Los Lunas had fewer blooms than at Alcalde (Fig. 3C). Comparing the four cultivars at Los Lunas, Harlayne had more flowers than Goldrich, Harogem, and Hargrand. Purvis (2006) mentioned when temperatures reached $40-50{ }^{\circ} \mathrm{F}$ during day time, apricot could be dehardened to only 
tolerate $0{ }^{\circ} \mathrm{F}$ in winter, and flower buds got almost $100 \%$ killed when the temperature dropped to $-12{ }^{\circ} \mathrm{F}$. Our results are similar to this report. We had 14 and $20 \mathrm{~d}$ of temperatures in the $50-60{ }^{\circ} \mathrm{F}$ range in Jan. 2011 at Alcalde and Los Lunas, respectively, and the $-11.3^{\circ} \mathrm{F}$ at Alcalde killed most of the flower buds on 2-year-old or older wood or those in the lower canopy. The $-13.9^{\circ} \mathrm{F}$ killed $98 \%$ to $99 \%$ of all apricot flower buds at Los Lunas.

From the apricot and peach observation results, it seems that flower buds that are initiated later, those less developed on the base of the shoots, and those on 1-year-old shoots were hardier than those on 2-year-old or older wood, which is in accordance with previous observations (Meyer and Okie, 1986). The better survival of flower buds on 1-year-old shoots could be partially due to their development delay compared with those on 2-yearold or older wood. So, if growers change their training and pruning techniques and rely on 1-year-old shoots for fruiting, apricot production may improve in areas affected by late frosts.

Plum flower bud damage. Japanese plum cultivars were severely injured during the freeze in early Feb. 2011. 'Santa Rosa' did not have enough flowers to acquire an acceptable crop even without late frosts (Fig. 3D; Table 3). European plum cultivars were less affected by the February freeze than japanese plum, with $87 \%$ live flower buds for 'Stanley' and almost 100\% for 'Castleton' and 'NY6' (Fig. 3E; Table 3). Even with minimal temperatures reaching $20^{\circ} \mathrm{F}$ in late March, european plum cultivars had not bloomed yet and therefore were able to avoid frost damage. However, most fruitlets were killed by late frosts in late April and early May (fruit 5-8 $\mathrm{mm}$ in diameter), with only a few european plums hanging on the trees to harvest.

Table 3. Plum flower bud winter damage evaluated on 26 Mar. 2011 at Alcalde, NM.

\begin{tabular}{lcc}
\hline Cultivar & $\begin{array}{c}\text { Total buds } \\
\text { (no.) }\end{array}$ & $\begin{array}{c}\text { Live buds } \\
\text { (\%) }\end{array}$ \\
\hline Santa Rosa & 1267 & 0.2 \\
Methley & 1593 & 4.8 \\
NY6 & 1003 & 99.6 \\
Castleton & 500 & 98.0 \\
Stanley & 518 & 87.0 \\
\hline
\end{tabular}

Cherry flower bud damage. Cherry, especially tart cherry, had less winter damage than peach and apricot. Sweet cherry cultivars suffered more damage than tart cherry cultivars, but they still fared better than japanese plum, apricot, and peach (Table 4). 'Rainier' had less than 30\% flower buds that bloomed, whereas
'Stella' had over $80 \%$ that bloomed. Around $50 \%$ of the bloomed flowers for 'Rainier' had damaged black pistils of $1-2 \mathrm{~mm}$ in length, which probably occurred early in the season, not during late frosts around blooming time (Fig. 4A; Table 4). 'BlackGold' had the highest percentage of flowers with normal pistils among the four sweet

Table 4. Cherry flower bud winter damage evaluated on 17 Apr. 2011 at Alcalde, NM.

\begin{tabular}{lcccc}
\hline Cultivar & $\begin{array}{c}\text { Total buds } \\
\text { (no.) }\end{array}$ & $\begin{array}{c}\text { Live buds } \\
(\%)^{\mathbf{z}}\end{array}$ & $\begin{array}{c}\text { Total flowers } \\
\text { (no.) }\end{array}$ & $\begin{array}{c}\text { Good pistils } \\
(\%)\end{array}$ \\
\hline Tart cherry & & & & \\
$\quad$ Balaton & 200 & 100 & 600 & 95.0 \\
$\quad$ Montmorency & 200 & 100 & 259 & 65.3 \\
$\quad$ Danube & 200 & 100 & 208 & 97.6 \\
Sweet cherry & & & & \\
$\quad$ WhiteGold & 328 & 39.3 & 100 & 68.0 \\
BlackGold & 324 & 78.4 & 100 & 95.0 \\
Rainier & 200 & 28.0 & 144 & 50.0 \\
Stella & 328 & 86.6 & 120 & 58.0 \\
\hline
\end{tabular}

${ }^{2}$ Buds with one or more flowers blooming were counted as live buds.
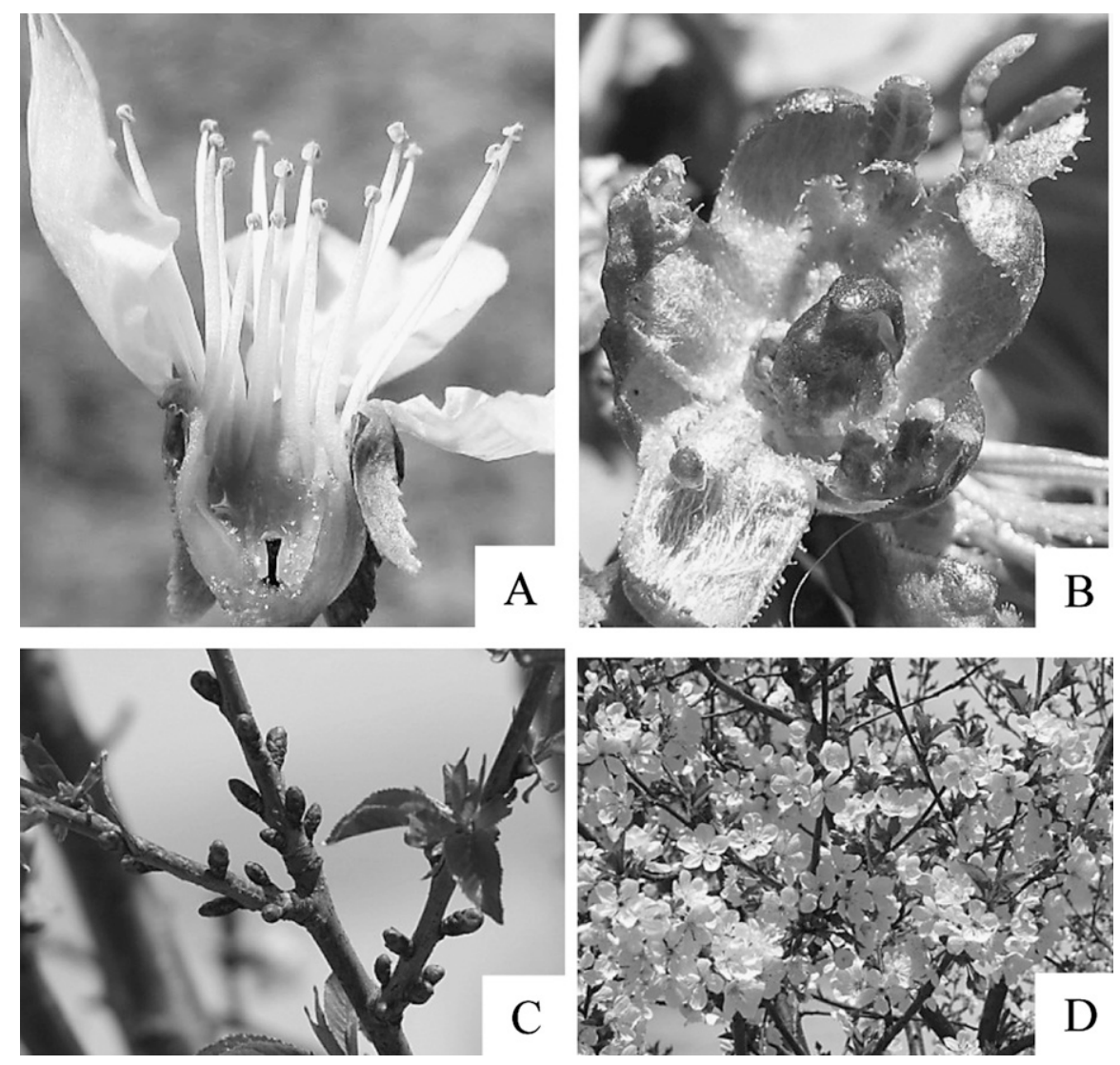

Fig. 4. Midwinter damage of cherry flower buds and blossoms during bloom time on 17 Apr. 2011, at Alcalde, NM. (A) Flower of 'Balaton' tart cherry with damaged pistil. (B) Damaged flower bud of 'Stella' sweet cherry at bloom with no petals, stamens, or pistils. (C) Delayed (damaged) flower buds of 'WhiteGold' sweet cherry that could not bloom or opened up with missing petals, stamens, or pistils and the worst case would be similar to B. (D) Full bloom of 'Danube' tart cherry. 
cherry cultivars examined (Table 4). Some damaged sweet cherry flower buds bloomed much later than others, without normal petals, sepals, and anthers, and flower stems were much shorter than normal (Fig. 4B and C).

All three tart cherry cultivar flower buds bloomed, but their pistil damage varied by cultivar, from $3 \%$ to $5 \%$ for Danube and Balaton (Fig. 4D; Table 4) to $34 \%$ for Montmorency. 'Montmorency' was less winter hardy than 'Balaton' and 'Danube'. The blooming time of 'Montmorency' lasted longer than that of all sweet and tart cherries. Unlike the delayed sweet cherry flower buds, the later buds of 'Montmorency' had healthy pistils as did its earlier buds.

For cherry, especially sweet cherry, the scales of each flower cluster were hardy, which made the buds look deceptively normal until dissection or bloom. If sweet cherry flower buds bloomed without petals, their pistils would also be damaged because they are less hardy than petals. Normal pistils are the foundation for the future crop. Tart cherry cultivars always bloom later and longer than sweet cherry, which give them a better chance to survive the late frosts. Even with the late April and early May frosts, the tart cherries still produced $20 \%$ of a full crop for 'Danube' and $25 \%$ to $50 \%$ of full crops for 'Montmorency' and 'Balaton' (data not shown).

For stone fruit species, the winterhardiness order, from hardy to tender, was: tart cherry, european plum and sweet cherry, japanese plum, apricot, and peach. Regional growers should therefore select fruit crop species according to their winter minimum temperatures and late frost conditions.

\section{Literature cited}

Cathy, H.M. 1990. USDA plant hardiness zone map. U.S. Natl. Arboretum, Agr. Res. Serv., U.S. Dept. Agr. Misc. Publ. No. 1475.

Matta, F.B., A.L. Torres, and B. Valdez. 1982. Air and soil temperatures and precipitation, Espanola Valley Branch Station, 1953-1980. New Mexico State Univ. Agr. Expt. Sta. Res. Rpt. 462.

Meyer, S.C. and W.R. Okie. 1986. Low midwinter temperature injury to peach flower buds in Georgia. Fruit Var. J. 40:136-139.
Murray, M. and H. Larsen. 2011. 2011 Utah-Colorado commercial tree fruit production guide. 12 Oct. 2011. <http:// www.colostate.edu/programs/wcrc/ pubs/publications/UT-CO\%20Tree\% 20Fruit $\% 20$ Guide, $\% 20$ final, $\% 20$-low $\%$ 20 res $\% 20$ (HL\%20corrected).pdf $>$.

New Mexico Climate Center. 2007. Weather data for New Mexico. 12 Oct. 2011. <http://weather.nmsu.edu/>.

New Mexico Department of Agriculture, New Mexico State University, and U.S. Department of Agriculture. 1979. New Mexico apple tree survey. New Mexico Dept. Agr., Las Cruces, NM.

New Mexico State University. 2011. New Mexico Coop Stations Freeze Date. 4 Oct. 2011. <http://nmclimate.nmsu.edu/ freeze $/>$.

Purvis, R.A. 2006. Apricots-A wide geographic possibility? Pomona 39:6-12.

University of California, Davis. 2011. Cumulative Chilling Hours. 5 Oct. 2011. <http://fruitsandnuts.ucdavis.edu/ chillcalc/indexl.htm>.

Young, R. 1987. West Virginia peach and nectarine fruit and vegetative bud injury and crop rating resulting from $-28{ }^{\circ} \mathrm{C}$ January temperature. Fruit Var. J. 41:68-72. 